Научная статья

УДК 616.31-083

DOI: $10.18101 / 2306-1995-2021-1-62-65$

\title{
РОЛЬ ГИГИЕНЫ ПОЛОСТИ РТА ПРИ ВОСПАЛИТЕЛЬНЫХ ЗАБОЛЕВАНИЯХ ПАРОДОНТА
}

\author{
(C) Намханов Вячеслав Владимирович \\ кандидат медицинских наук, доцент, \\ Бурятский государственный университет имени Доржи Банзарова \\ Россия, 670002, г. Улан-Удэ, ул. Октябрьская, 36а \\ namhanov@yandeex.ru
}

\author{
(C) Писаревский Юрий Леонидович \\ доктор медицинских наук, профессор, \\ заведующий кафедрой ортопедической стоматологии \\ Читинская государственная медицинская академия \\ Россия, 672038, г. Чита, ул. Новобульварная, 163 \\ ypisarevskij@mail.r
}

\begin{abstract}
Аннотация. Статья посвящена заболеванию десен, в основе которого лежит процесс склерозирования сосудов, уменьшения поступления кислорода и питательных веществ, а также дистрофия всех тканей пародонта. При пародонтите воспалительная убыль костной ткани происходит с образованием пародонтальных карманов.

При пародонте происходит равномерная горизонтальная убыль костной ткани в области всех зубов. Диагноз выставляется при визуальном осмотре, рентгенологически. Лечение, как правило, - это массаж пальцами десен, физиотерапия, медицинская терапия, избирательное пришлифовывание зубов, шинирование подвижных зубов. Ключевые слова: гигиена, полость рта, воспаление, зубы, гингивит, пародонтоз, пародонтит, костная ткань
\end{abstract}

\section{Для цитирования}

Намханов В. В., Писаревский Ю. Л. Роль гигиены полости рта при воспалительных заболеваниях пародонта // Вестник Бурятского государственного университета. Медицина и фармация. 2021. Вып. 1. С. 62-65.

Основными заболеваниями пародонта, с которыми обращаются на прием пациенты, являются пародонтит и гингивит. Пародонтит представляет собой воспалительно-деструктивное заболевание, приводящее к разрушению связочного аппарата десны и деструкции костной ткани, окружающей зуб. Гингивит представляет воспаление десны без разрушения связочного аппарата и без деструкции кости. Главной причиной заболеваний десен является бактериальный налет, который образуется при плохой гигиене полости рта. Если налет не удалять, он минерализуется и становится дополнительным ретенционным пунктом, оказывая местное раздражающее действие на десну, нарушает процесс самоочищения пародонтального кармана, поддерживает воспалительно-деструктивные процессы. Поэтому хорошая гигиена полости рта является обязательным условием успешного лечения и профилактики заболеваний пародонта.

Профессиональная гигиена заключается в максимально возможном устранении налета и зубного камня с помощью специальных инструментов и аппара- 
В. В. Намханов, Ю. Л. Писаревский. Роль гигиены полости рта при воспалительных заболеваниях пародонта

тов, а также в оценке гигиенического состояния полости рта путем определения индекса гигиены, обучении правилам чистки зубов с последующим контролем. После выполнении врачом этих задач большая ответственность за поддержание хорошей гигиены полости рта ложится на пациента. Индивидуальная гигиена полости рта заключается в ежедневной двухкратной чистке зубов (утром после завтрака и вечером перед сном) в течение трех минут. Не секрет, что многие пациенты не владеют правилами гигиены полости рта, не имеют для этого необходимых знаний и навыков. Поэтому с каждым пациентом индивидуально проводятся беседа и обучение навыкам гигиены полости рта. При заболеваниях пародонта предпочтение следует отдавать лечебно-профилактическим паста («Пародиум», «Эльгидиум», «Лесной бальзам», «Пародонтакс», «Лакалут актив», «Глистер»). Зубная щетка подбирается индивидуально в соответствии с тяжестью течения заболеваний пародонта и меняется через 3 месяца. Помимо основных средств и предметов гигиены используются дополнительные: ополаскиватели, флоссы, ершики, жевательные резинки.

За 2018 год нами был обследован 321 человек с воспалительными заболеваниями пародонта. Из них 56\% составили больные в возрасте от 20 до 30 лет, 33\% 30-45 лет, 11\% - 45-60 лет. Из 321 больного 45\% были с диагнозом «Хронический генерализованный пародонт различной степени тяжести», у 55\% был определен гингивит (рисунок 1), они по возрасту распределились следующим обра3ом: 48\% больных были в возрасте от 20 до 30 лет, 27\% - 30-45 лет, 25\% 45-60 лет. Больные женского пола составили 67\%, мужского - 33\%. Наиболее часто встречаемой формой в возрастной группе до 30 лет был катаральный гингивит, хронический генерализованный пародонтит преобладал в возрастной группе 35-45 лет. Необходимо отметить, что воспалительно-деструктивные формы уже встречаются у лиц молодого возраста (25-30 лет) (рисунок 1). Вместе с тем больные в данной группе были более восприимчивы к проводимому лечению, выполняли все рекомендации. У них эффект от проводимого лечения наступал быстро, удавалось достичь стойкой мотивации, приобретенные навыки по гигиене полости рта закреплялись хорошо.

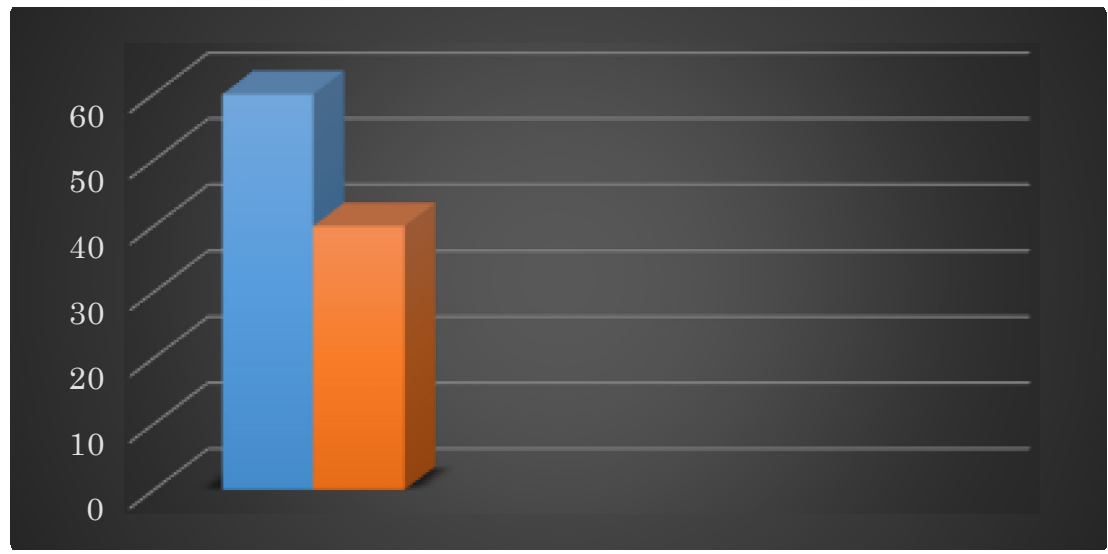

\%заболеваемости

Рис. 1. Структура воспалительных заболеваний пародонта 


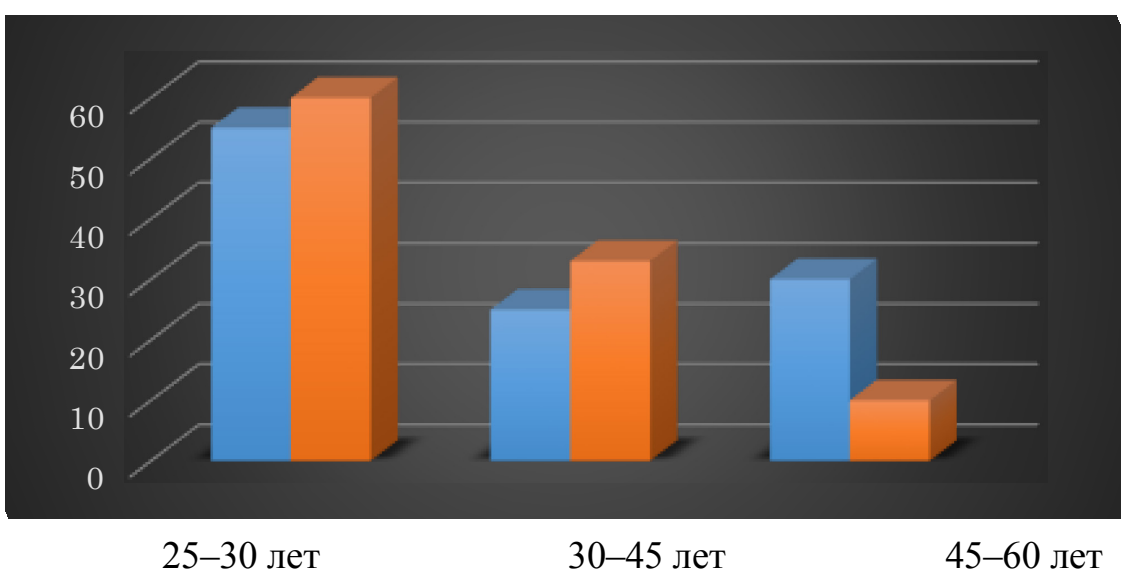

Рис. 2. Заболеваемость пародонтитом и гингивитом в зависимости от возраста

Каждому пациенту в первое посещение проводили оценку гигиенического состояния полости рта путем определения индекса гигиены по ФедоровуВолодкиной, обучение правилам гигиены полости рта, используя наглядные пособия - брошюры, плакаты, муляжи, что является более эффективным способом объяснить пациенту необходимость улучшения индивидуальной гигиены, а также осуществлялась последующая контролируемая чистка зубов. Затем в это же посещение проводили профессиональную гигиену полости рта. Зубные отложения удаляли с использованием ультразвукового аппарата «Мини=Пьезон», кюрет Грейса, чистку зубов проводили циркулярной щеткой и абразивной пастой «Детатрин $Z$ », антисептическую обработку полости рта - 3\%-ным раствором перекиси водорода и $0,05 \%$-ным раствором хлоргексидина с последующей аппликацией диплен-пленок на основе метрогила, линкомицина, хлоргексидина, геля «Холисал», «Метрогил=Дента». Во второе посещение повторно проводилось определение гигиенического индекса по Федорову-Володкиной.

Пациентам с хорошим индексом гигиены планово проводили комплексное лечение, включающее в себя взаимодействие терапевтических, хирургических, ортопедических и ортодонтических методов лечения с последующей постановкой на диспансерный учет.

Пациентам с плохим и удовлетворительным индексом гигиены, который определялся на протяжении 3-4 посещений, несмотря на проводимые мероприятия и беседы, осуществляли симптоматическое лечение, так как планировать и проводить более сложное и трудоемкое лечение у таких пациентов малоэффективно, а потому нецелесообразно.

Вывод. Таким образом, успех лечения заболеваний пародонта зависит не только от проведенных врачом манипуляций, но и от желания и готовности пациента сотрудничать с врачом, выполнять его рекомендации. Пока мы не научим и не приучим население к правильной гигиене полости рта, пока потребность в уходе за полостью рта не будет на уровне подсознания, все проводимые мероприятия в кабинете стоматолога и профилактические программы будут малоэффективны. Мировой опыт подтверждает правоту и значимость гигиенических 
В. В. Намханов, Ю. Л. Писаревский. Роль гигиены полости рта при воспалительных заболеваниях пародонта

мероприятий в полости рта как основной способ сохранить здоровыми не только зубы, но и пародонт.

\section{Лuтература}

1. Васильева А. Ю. Лучевая диагностика в стоматологии. Национальное руководство. Москва, 2012. 288 с. Текст: непосредственный.

2. Куликов А. Т. Фотодинамическая терапия в комплексном лечении воспалительных заболеваний пародонта: автореферат диссертации на соискание ученой степени кандидата медицинских наук. Санкт-Петербург, 2018. С. 21-23. Текст: непосредственный.

3. Диагностика заболеваний пародонта: руководство / С. С. Бутейко; под ред. В. К. Федорова, Н. В. Шохина. Москва, 2018. 416 с. Текст: непосредственный.

4. Минеральная плотность костной ткани и кардиоваскулярная патология при ревматоидном артрите / Н.А. Храмцов [и др.] // Сибирский медицинский журнал. 2012. Т. 85, № 2. С. 54-56. Текст: непосредственный.

Статья поступила в редакиию 09.01.2021; одобрена после рецензирования 25.01.2021; принята к публикации 09.04.2021.

\section{ROLE OF ORAL HYGIENE IN TREATMENT \\ OF INFLAMMATORY PERIODONTAL DISEASES}

Vyacheslav V. Namkhanov

Cand. Sci. (Medicine), A/Prof.,

Dorzhi Banzarov Buryat State University

36a Oktyabrskaya St., Ulan-Ude 670002, Russia

namhanov@yandeex.ru

Yury L. Pisarevsky

Dr. Sci. (Medicine), Prof.,

Head of Prosthetic Dentistry Department

Chita State Medical Academy

163 Novobulvarnaya St., Chita 672038, Russia

ypisarevskij@mail.ru

Abstract. The article is devoted to a gum disease, which is characterized by the process of vascular hardening, hypooxygenatiion and nutritional deficiency, as well as by dystrophy of all periodontal tissues. In periodontitis, inflammatory bone loss leads to the formation of periodontal pockets.

Periodontitis causes a homogeneous horizontal loss of bone tissue in dentition. The disease is revealed by visual examination, and radiologically. Treatment usually includes finger massage of the gums, physiotherapy, medical therapy, selective grinding, and splinting of mobile teeth.

Keywords: hygiene, oral cavity, inflammation, teeth, gingivitis, parodontosis, paradontitis, bone tissue.

For citation

Role of Oral Hygiene in Treatment of Inflammatory Periodontal Diseases. Bulletin of Buryat State University. Medicine and Pharmacy. 2021; 1: 62-65 (In Russ.).

The article was submitted 09.01.2021; approved after reviewing 25.01.2021; accepted for publication 09.04.2021. 